\title{
GISにおける文字の大きさの統計的決定手法
}

\author{
貞広幸雄
}

\section{A Statistical Method for Determining the Size of Map Labels}

\author{
Yukio SADAHIRO
}

\begin{abstract}
This paper proposes a method for determining the size of map labels from a statistical view. Though larger letters are more readable than smaller ones, they sometimes cause the overlaps of letters, and thus it may leads the inefficiency of GIS operations. In this paper, we show two indices for evaluating the readability of map labels: visible letter area and readable letter area. The former is the area of rectangles in computer display which include letters of map labels. The latter is also the summed area of rectangles, though it excludes overlapped rectangles. These indices are calculated in several cases, and we show the relationship between these indices and the size of:letters. 'We'can:thus expect the area of overlapped letters statistically, and control it by adopting letters of propersize. This methodris applied to the names of stations in Yokohama, and some empirical findings are shown.
\end{abstract}

Keywords: map labels, size of letters, name placement, statistical method

\section{1. はじめに}

地理情報システムにおけるデータ表示機能は、通 常、空間的なオブジェクトだけではなく、各オブジ エクトに付随する属性情報も対象としている。施設 名称や属性の数值データなどの文字情報は、地理情 報システムが扱うデータの中でも最も重要な情報の 一つであり、システムは利用者がそれらを正しくか つ素早く認識できるように表示する必要がある。

文字情報の見易さは様々な要因によって決定され るが、最も重要なものの一つとして、文字の大きさ が挙げられるであろう。文字は、一般的に大きけれ ば大きいほど判読しやすいが、文字を大きくし過ぎ ると情報量が多くなったときに文字同士の重複や画 面からのはみ出しが発生し、かえって判読が困難に なる。文字を小さくすると、重複やはみ出しの問題 を避けることはできるが、文字の小ささが読み易さ

\section{貞広：干113 東京都文京区本郷7-3-1 - 東京大学工学部} 都市工学科 Tel. 03-5800-6964

Department of Urban Engineering, University of Tokyo 7-3-1 Hongo, Bunkyo, Tokyo 113

E-mail: sada@okabe.t.u-tokyo.ac.jp
を阻害することになる。

このように、文字の大きさはその見易さに多大な 影響を与えるため、文字の大きさを決定するときに は、文字情報の量に応じて文字の重複やはみ出しな どを慎重に考慮する必要がある。しかし従来、文字 の大きさは経験的に決定されることが多く、文字が 重複して十分に判読できないということがしばしば 起こっていた。

例えぱ、地理情報システムを用いて何らかの空間 的解析を行うときを考えてみよう。このような場合、 利用者は地図情報を何度も繰り返し見る必要があり、 システムには情報を素早く表示することが求められ る。このため文字情報は、システム既定の大きさで 機械的に配置されることが多い。しかしこの場合、 表示される文字の大きさが大き過ぎると、文字情報 の数が多くなった場合に文字の判読が難しくなり、 解析作業の効率を低下させる恐れがある。

あるいは、地理情報システムにおいて地図の最終 的な出力図面を作成する場合を考えてみよう。この 
場合、出力図面においては全ての文字を判読できる ことが要求されるため、図面中における同色文字の 重複は原則として許されない（Yoeli, 1972; Imhof, 1975; Buttenfield and McMaster, 1991）。そのため、 文字同士が重複しないように配置を行う方法として、 automated name placement（自動文字配置）と呼ばれ ろアルゴリズムがいくつか提案されてきた（Hirsch, 1982; Ahn and Freeman, 1983; Zoraster and Stephen, 1987; Doerschler and Freeman, 1989; Ebinger and Goulette, 1989）。これらのアルゴリズムを用いるこ とにより、図面中における文字同士の重複はかなり 減少する。しかしこの場合も、文字の大きさはシス テム利用者が経験的に適切であると考える大きさに 設定するため、経験の浅い利用者は、文字の重複の ない図面が完成するまでに何度も字の大きさを変え て表示を試みたり、一部の文字情報を削除するなど の必要が生じていた。もちろん、文字同士が重複し ないという条件のもとで、文字の大きさの最大值を 解析的に求めることができれば、このような問題は 解決される。しかしFormann and Wagner(1991)によれ ば、文字情報領域が全て合同であるという極めて単 純な場合ですら、そのような計算はNP完全である ことが証明されており、Nが大きい場合には極めて 難しい問題となる。

このような状況をふまえ、本論文では文字情報を 完全に機械的に配置する、つまり、特別なアルゴリ ズムを用いずに配置する場合を取り上げ、統計的手 法によって、文字の大きさが画面からのはみ出しゃ 文字同士の重複といった情報損失に与える影響を定 量的に分析する。このような研究を行う目的は二つ ある。第一には、空間解析の途中段階のように、文 字の判読し易さよりも表示時間の方が重視される状 況において、文字情報の損失を一定水準以下に抑え、 文字の見易さを確保するための文字の大きさの基準 を示すことである。第二の目的は、機械的な文字配 置における文字の大きさの基準を示すことで、自動 文字配置アルゴリズムを用いた場合における安全な 基集を示唆することである。機械的な配置を行う場
合、文字配置アルゴリズムによってうまく文字が配 置された場合と比べると文字情報の損失は多くな る。これは逆に考えれば、機械的配置における文字 の大きさの基準值は、様々なアルゴリズムを用いた ときの安全側の基準值となるということであり、こ の結果を利用することで、自動文字配置においても 予想外の情報損失という事態を避けることができる。

以下、2 節では文字情報が画面からはみ出すこと による損失に着目し、文字の大きさが文字情報の損 失量に与える影響を分析する。3節でははみ出しに 加え、文字の重複も考慮した考察を行う。4節では 前 2 節の結果をふまえ、横浜市の地図について実際 に文字の大きさを決定し、配置した例を示す。5節 では本論文から得られる知見と今後の課題について まとめる。

\section{2. 画面からのはみ出しによる文字情報の損失}

いま、地図の出力対象領域 $\mathrm{A}$ 長方形（横 $\mathrm{X}_{0}$ 、紸 $\mathrm{Y}_{0}$ 、面積 $\left.\mathrm{S}_{0}\right)$ のコンピュータディスプレイと仮定 し、この中にN個の施設がランダムに配置されてい る場合を考えよう。なお、ここでは問題を単純化す るために、施設は全て点的施設であるものとする。 各施設は、全て施設名称などの属性データを持ち、 属性データのうちの一つを文字情報としてコンピュ 一タディスプレイ上に表示するものとする。これら 点的施設以外の施設や、その他の文字情報、ディス プレイ外に存在する点的施設の文字情報は一切表示 されない。文字情報の一部がディスプレイからはみ 出す場合には、その文字情報はディスプレイ内に収 まる範囲だけ表示される。点的施設にに付随する文 字情報領域は、文字情報を完全に包含する最小の長 方形領域（向きは水平方向）とし、この領域を $\mathrm{L}_{\mathrm{i}}$ と 呼ふ（横 $\mathrm{X}_{\mathrm{i}}$ 、紸 $\mathrm{Y}_{\mathrm{i}}$ 、面積 $\mathrm{S}_{\mathrm{i}}$ )。通常、文字情報の大 きさはディスプレイの大きさと比べてかなり小さい ので、本論文では $\mathrm{X}_{0} / 2>\mathrm{X}_{\mathrm{i}}, \mathrm{Y}_{\mathrm{i}} / 2>\mathrm{Y}_{\mathrm{i}}(\mathrm{i}=1, \ldots, N)$ と する。

文字情報の配置は完全に機械的であり、点的施設に 対して図1のような位置関係で置かれるものとする。 

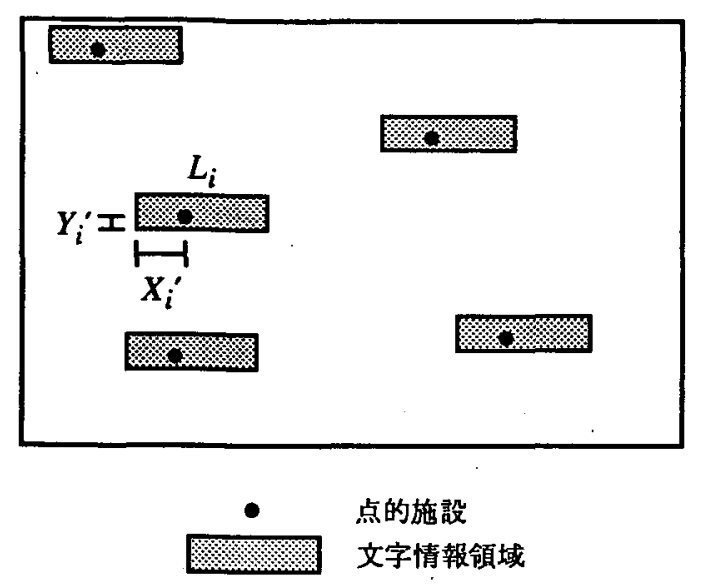

図1 文字情報の配置方法

本論文では、以上の条件の下で、文字の大きさが 文字のはみ出しや重複といった情報損失に与える影 響を統計的に分析する。なお、点的施設と文字情報 は異なる方法によって表示される（異なる色を用い るなど）ものとし、文字情報と施設表示の重複はこ こでは特に扱わない。

まずはじめに、文字の情報量を次のように定義し ておこう（但し $M=\{1,2, \ldots, N\}$ とする）。

全情報量 : $\quad I_{\text {total }}=\sum_{i=1}^{N} S_{i}$

画面内情報量 $: I_{\text {in }}=\sum_{i=1}^{N} \operatorname{area}\left[A \cap L_{i}\right]$

有效情報量 : $I_{\text {eff }}=\sum_{i=1}^{N} \operatorname{area}\left[A \cap L_{i}-\bigcup_{j \in M, j \neq i} L_{j} \cap L_{i}\right](2.3)$

全情報量とは、全ての文字情報が持つ情報量の総 和であり、各文字情報領域の面積の合計として表さ れる。画面内情報量とは、文字情報領域のうち画面 からのはみ出しによって失われたものを除いた部分 の面積である。有効情報量とは、画面内に含まれる 文字情報のうち、複数の文字情報が重複していない 部分の面積を表す。
本論文では、これらの情報量から、画面内情報率 （画面内情報量の、全情報量に対する比率）と有効 情報率（有効情報量の、全情報量に対する比率）を 算出し、システム利用者が入手し得る文字情報量の 指標とする。画面内情報率と有効情報率は、どちら も判読可能性のある文字情報の割合を示しているが、 前者は判読可能性が0ではない部分を全て対象とし ているのに対し、後者はより判読可能性の高い部分 のみを対象としているという違いがある。

これらの情報率のうち、本節では画面内情報率の 期待値を求めることによって、文字の大きさが画面 からの文字のはみ出しに与える影響を分析する。こ の値は、各文字情報について画面内に含まれる部分 の面積の期待值を計算し、その総和を全情報量で除 することによって求めることができる。そこでここ では文字情報領域 L について、画面内に含まれる領 域面積の期待值を計算する。

はじめに、計算のためにディスプレイに図 2 のよ うな座標系をとり、さらにこのディスプレイ画面を 図3のような 9 つの領域に分割する。

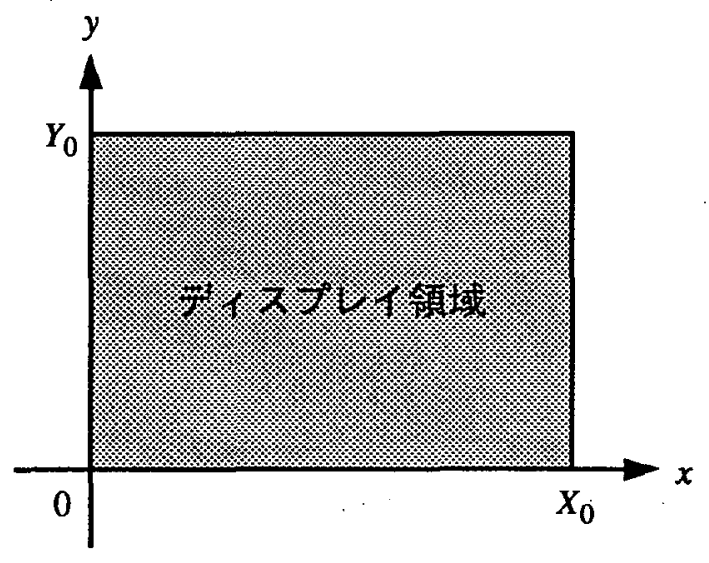

図 2 ディスブレイ内の座標系

次に図 3 の各領域について、点的施設到図 4 の ような微小領域dAに含まれる確率及びその時の画面 内情報量を計算する。この値を各領域内で積分する ことによって、点的施設仿各領域に含まれるとき の画面内情報量の期待值を求めることができる。な お、以下の説明では、点的施設iが領域にに含まれると 
きの画面内情報量の期待值の総和を $\mathrm{I}_{\mathrm{ij}}$ とする。

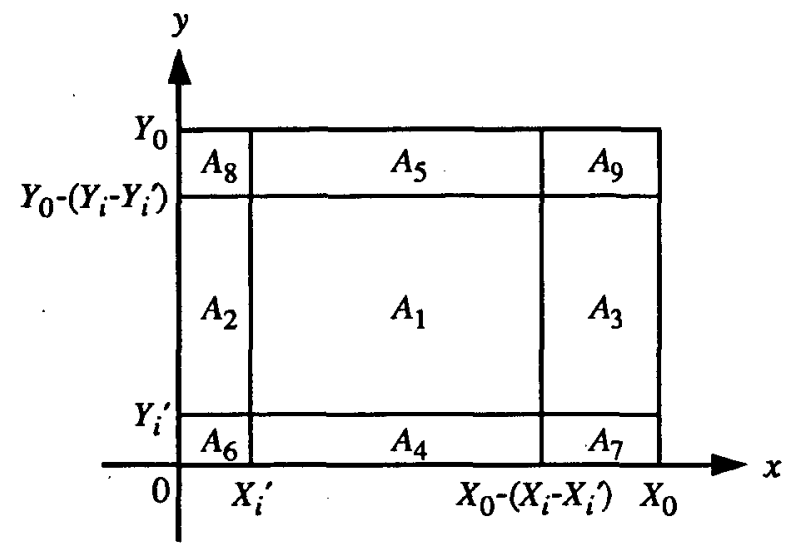

図 3 画面内情報率を計算するための9つの領域

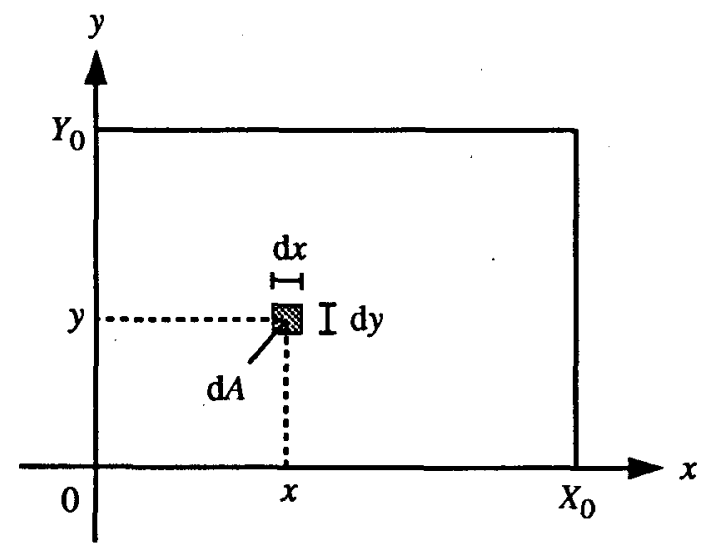

図 4 微小領域 $\mathrm{dA}$

\section{(1)点的施設が領域 $A_{1}$ に含まれる場合}

点的施設活微小領域 $d \mathrm{~A}$ に含まれる確率は $\mathrm{d} x \mathrm{~d} y / S_{0}$ であり、このときの画面内情報量はSである。従っ て、画面内情報量の期待値 $I_{i 1}$ は

$$
\begin{aligned}
I_{i 1} & =\int_{x=X_{i}^{\prime}}^{X_{0}-\left(x_{i}-X_{i}^{\prime}\right)} \int_{y=X_{i}^{\prime}}^{Y_{0}-\left(Y_{i}-x_{i}^{\prime}\right)} S \frac{\mathrm{d} y \mathrm{~d} x}{S_{0}} \\
& =\frac{\left(X_{0}-X_{i}\right)\left(Y_{0}-Y_{i}\right)}{S_{0}} S
\end{aligned}
$$

となる。

(2)点的施設が領域 $\mathrm{A}_{2} \sim \mathrm{A}_{5}$ に含まれる場合 点的施設汭領域 $A_{2}$ 内の微小領域 $\mathrm{d} A$ に含まれると
きの画面内情報量は、

$$
\left(x+X_{i}-X_{i}^{\prime}\right) Y_{i}
$$

である。従って画面内情報量の期待値 $\mathrm{I}_{\mathrm{i} 2}$ は

$$
\begin{aligned}
I_{i 2} & =\int_{x=0}^{X_{i}^{\prime}} \int_{y=Y_{i}^{\prime}}^{Y_{0}-\left(Y_{i}-Y_{i}^{\prime}\right)}\left(x+X_{i}-X_{i}^{\prime}\right) Y_{i} \frac{\mathrm{d} y \mathrm{~d} x}{S_{0}} \\
& =\frac{\left(2 X_{i}-X_{i}^{\prime}\right) X_{i}^{\prime}\left(Y_{0}-Y_{i}\right) Y_{i}}{2 S_{0}}
\end{aligned}
$$

と表される。領域 $A_{3} \sim A_{5}$ についても同じように、

$$
\begin{aligned}
& I_{i 3}=\frac{\left(X_{i}-X_{i}^{\prime}\right)\left(X_{i}+X_{i}^{\prime}\right)\left(Y_{0}-Y_{i}\right) Y_{i}}{2 S_{0}} \\
& I_{i 4}=\frac{\left(X_{0}-X_{i}\right) X_{i}\left(2 Y_{i}-Y_{i}^{\prime}\right) Y_{i}^{\prime}}{2 S_{0}} \\
& I_{i 5}=\frac{\left(X_{0}-X_{i}\right) X_{i}\left(Y_{i}-Y_{i}^{\prime}\right)\left(Y_{i}+Y_{i}^{\prime}\right)}{2 S_{0}}
\end{aligned}
$$

と画面内情報量の期待値が計算される。

(3)点的施設が領域 $\mathrm{A}_{6} \sim \mathrm{A}_{9}$ に含まれる場合

点的施設 $i か ゙$ 微小領域 $\mathrm{d} A$ に含まれるときの画面内 情報量は、

$$
\left(x+X_{i}-X_{i}^{\prime}\right)\left(y+Y_{i}-Y_{i}^{\prime}\right)
$$

である。従って画面内情報量の期待值 $\mathrm{I}_{\mathrm{i} 6}$ は

$$
\begin{aligned}
I_{i 6} & =\int_{x=0}^{X_{i}^{\prime}} \int_{y=0}^{Y_{i}^{\prime}}\left(x+X_{i}-X_{i}^{\prime}\right)\left(y+Y_{i}-Y_{i}^{\prime}\right) \frac{\mathrm{d} y \mathrm{~d} x}{S_{0}} \\
& =\frac{\left(2 X_{i}-X_{i}^{\prime}\right) X_{i}^{\prime}\left(2 Y_{i}-Y_{i}^{\prime}\right) Y_{i}^{\prime}}{4 S_{0}}
\end{aligned}
$$

となる。領域 $\mathrm{A}$ ～Ａ，についても同様の考え方により、

$$
\begin{aligned}
& I_{i 7}=\frac{\left(X_{i}-X_{i}^{\prime}\right)\left(X_{i}+X_{i}^{\prime}\right)\left(2 Y_{i}-Y_{i}^{\prime}\right) Y_{i}^{\prime}}{4 S_{0}} \\
& I_{i 8}=\frac{\left(2 X_{i}-X_{i}^{\prime}\right) X_{i}^{\prime}\left(Y_{i}-Y_{i}^{\prime}\right)\left(Y_{i}+Y_{i}^{\prime}\right)}{4 S_{0}} \\
& I_{i 9}=\frac{\left(X_{i}-X_{i}^{\prime}\right)\left(X_{i}+X_{i}^{\prime}\right)\left(Y_{i}-Y_{i}^{\prime}\right)\left(Y_{i}+Y_{i}^{\prime}\right)}{4 S_{0}}
\end{aligned}
$$


となる。

以上の計算䊅果より、画面内情報率の期待值は次 のように求められる。

$\frac{\sum_{i=1}^{N} \sum_{j=1}^{g} I_{i j}}{\sum_{i=1}^{N} S_{i}}=\frac{\sum_{i=1}^{N}\left(2 X_{0} X_{i}+2 X_{i} X_{i}^{\prime}-X_{i}^{2}-2 X_{i}^{\prime 2}\right)\left(2 Y_{0} Y_{i}+2 Y_{i} Y_{i}^{\prime}-Y_{i}^{2}-2 Y_{i}^{\prime 2}\right)}{4 S_{0} \sum_{i=1}^{N} S_{i}}$

ここで、点的施設と文字情報領域の位置関係につ いて考えてみよう。文字情報が機械的に配置される 場合には、文字情報領域は点的施設に対して図 5 の いずれかの泣置に置办れること加普通である。Yoeli (1972)では、(a)の4のの位置が最も望ましく、それ が無理な場合には(b)の汸に配置すべきてある述 ベられている。しかし、(2.11)式から分かるとおり、 画面内情報率の期待值は、 $\mathrm{X}_{\mathrm{i}}^{\prime}=\mathrm{X}_{i} 2 、 \mathrm{Y}_{\mathrm{i}}^{\prime}=\mathrm{Y}_{i} / 2$ のと、 つまり、図 5 (c)のように点的施設が文字情報領域の 重心に位置するような配置において最大值をとり、 (a)の場合は最小値をとる。点的施設と文字情報領域 の位置関係は、施設と文字の関係づけの容易さなど の観点も含めて総合的に決定されるべき問題である が、機械的な配置において画面からの文字のはみ出 しを防ぐという観点から見れば、(a)ような配置より も(c)あるいは(b)のような配置の方が望ましいこと が分かる。

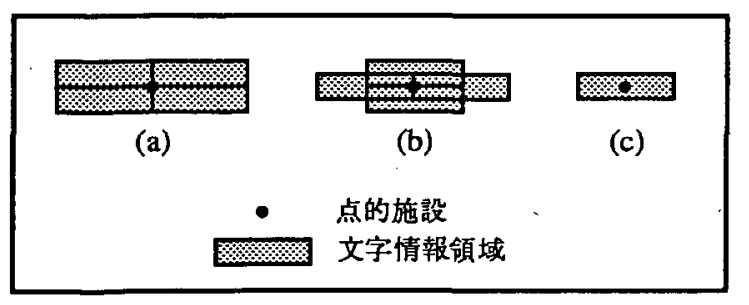

図 5 文字情報領域と点的施設の位置関係

次に、(2.11)式を実際のディスプレイ画面に適用 し、文字の大きさと画面内情報率の関係を見てみよ う。いま、横640、縦400ドットのディスプレイがあ り、その中に複数個の点的施設がランダムに配置さ れるものとする。全ての施設には、漢字 3 文字の名
称がつけられており、各文字の維横の長さは同じも のとする(これは、各文字情報領域が全て合同であ ク、絴横比が $1 ： 3$ ということを意味する）。文字 情報領域は常に点的施設の右上、つまり、 $X_{i}^{\prime}=Y_{i}^{\prime}=0$ となるように犆かれる。このとき、画面内情報率と 文字情報領域の大きさの関係はどうなるであろうか。

この計算は、(2.11)式において $\mathrm{Y}_{\mathrm{i}}=\mathrm{Y} 、 \mathrm{X}_{\mathrm{i}}=\mathrm{X}=3 \mathrm{Y}$ を 代入し、数値計算を行えばよい。すると結果は図 6 のようになる。

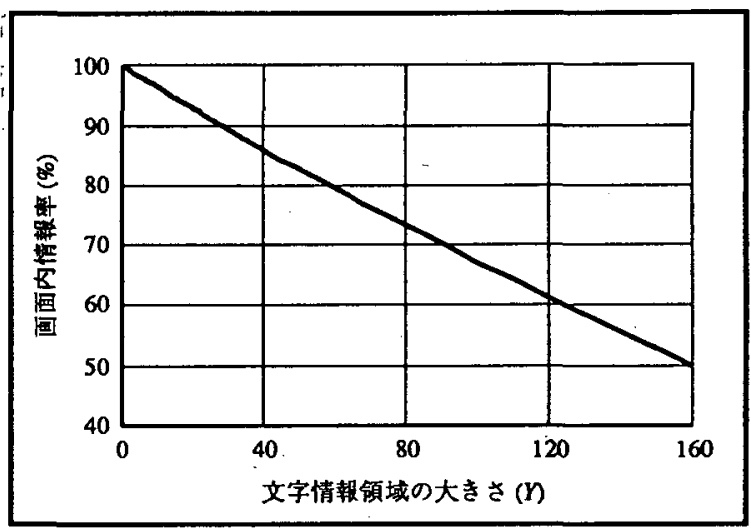

図 6 文字情報領域の大きさと画面内情報率

この場合、文字情報領域の大きさと画面内情報率 の間には、直線に近い関係があることが分かる。こ こで、日本のコンピュータディスプレイでよく用い られる $12 \times 12$ ドット、 $16 \times 16$ ドット、 $24 \times 24$ ドット の 3 つの字体の大きさについて、画面内情報率を見 てみよう。画面内情報率の期待值は、図6よりそれ ぞれ95。7\%、94.3\%、91.5\%である。つまり、10\% のはみ出しが許容できるならば、 $24 \times 24$ ドットとい う比較的良好な大きさの字体を用いることも可能で あるが、そうでなければより小さな字体を用いる方 がよいということになる。

次に、文字情報領域が点的施設の真下に配置され る、つまり $\mathrm{X}_{\mathrm{i}}^{\prime}=\mathrm{X}_{\mathrm{i}} / 2 、 \mathrm{Y}_{\mathrm{i}}=0$ と仮定してみよう。する と、画面内情報率はそれぞれ97.12\%、96.1\%、94.3\%に 增加する。従ってこの場合、文字の大きさが大きい ほど、点的施設と文字情報領域の位置関係が画面か らの文字のはみ出しに与える影響が大きくなること 
が分かる。

\section{3. 画面からのはみ出し及び文字の重複による} 文字情報の損失

本節では有効情報率の期待値を指標として用い、 文字の大きさが文字のはみ出し及び文字同士の重複 に与える影響を定量的に分析する。

有効情報率の期待值は、一般的には次のように求 めることができる。図 2 の座標系において、画面内 の点 $(x 、 y)$ の上に文字情報領域 $L_{\mathrm{i}}$ が置かれる確率は、

$\frac{\min \left\{X_{i}, x+X_{i}^{\prime}, X_{0}-x+X_{i}-X_{i}^{\prime}\right\} \min \left\{Y_{i}, y+Y_{i}^{\prime}, Y_{0}-y+Y_{i}-Y_{i}^{\prime}\right\}}{S_{0}}$

である。一方、 Li 以外の文字情報領域が全て点 $(x, y)$ に重ならない確率は、

$\prod_{j \in M, j \neq i}\left(1-\frac{\min \left\{X_{j}, x+X_{j}^{\prime}, X_{0}-x+X_{j}-X_{j}^{\prime}\right\} \min \left\{Y_{j}, y+Y_{j}^{\prime}, Y_{0}-y+Y_{j}-Y_{j}^{\prime}\right\}}{S_{0}}\right)$

である。有効情報量 $\mathrm{I}_{\text {eff }}$ は、文字情報領域が一つだけ 置かれる部分の面積であるから、式(3.1)と(3.2)の積 のiに関する和を、画面領域Aについて積分すること によって求められる。従って有効情報率は、

$\frac{1}{\sum_{i=1}^{N} S_{i}} \int_{x=0}^{X_{0}} \int_{y=0}^{x_{i}} \sum_{t=1}^{N}\left[\frac{\min \left\{X_{i}, x+X_{i}^{\prime}, X_{0}-x+X_{i}-X_{i}^{i}\right\} \min \left\{Y_{i}, y+Y_{i}^{\prime}, Y_{0}-y+Y_{i}-Y_{i}^{\prime}\right\}}{S_{0}}\right.$ $\left.\prod_{j=0, j, y+\infty}\left(1-\frac{\min \left\{X_{j}, x+X_{j}^{\prime}, X_{0}-x+X_{j}-X_{j}^{\prime}\right\} \min \left\{Y_{j}, y+Y_{j}^{\prime}, Y_{0}-y+Y_{j}-Y_{j}^{\prime}\right\}}{S_{0}}\right)\right] d x d y$

となる。しかし、(3.3)式を使って文字情報領域の大 きさと有効情報率の関係を具体的に捉えるすること は難しいので、以下、いくつかの限定的な場合につ いて(3.3)式をさらに単純化し、文字情報領域の大き さが有効情報率に与える影響を調べる。

3.1 全ての文字情報領域が合同な場合
まず、全ての文字情報領域が合同な場合を考えよ う。この場合、 $X_{i}=X 、 Y_{i}=Y 、 X_{i}^{\prime}=X^{\prime} 、 Y_{i}^{\prime}=Y^{\prime} 、 S_{i}=S$ とする。次に、画面領域Aを図7のような9つの領域 に分割し、各領域の点 $(x, y)$ に文字情報領域が一つだ け置かれる確率を求める。この確率を領域ごとに皘 分し、領域iに関する有効情報量の期待值の総和を

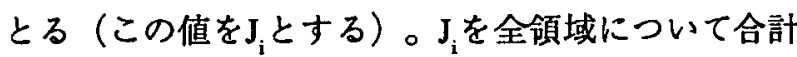
すれば、有効情報量 $\mathrm{I}_{\mathrm{eff}}$ 及び有効情報率の期待値を求 めることができる。

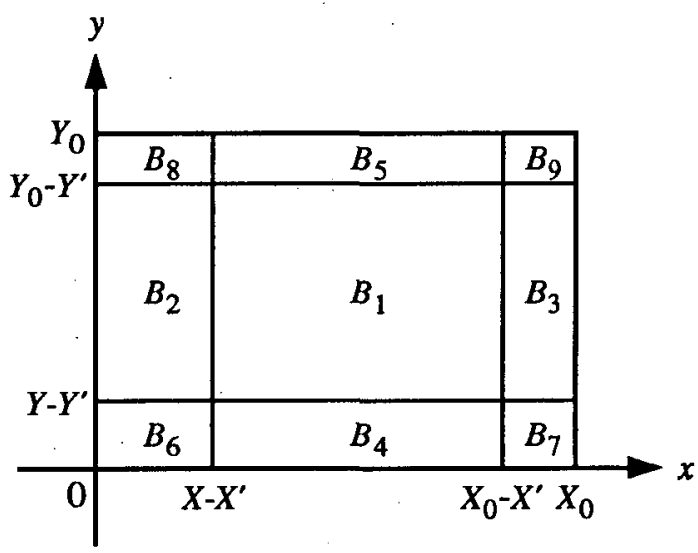

図 7 有効情報率を計算するための9つの領域

(1)領域 $\mathrm{B}_{1}$ に関する期待值 $\mathrm{J}_{1}$ 領域 $\mathrm{B}_{1}$ 内の点 $(\mathrm{x}, \mathrm{y})$ に文字情報領域が一つだけ置か れる確率は、

$$
N\left(\frac{S}{S_{0}}\right)\left(1-\frac{S}{S_{0}}\right)^{N-1}
$$

と表される。この確率を領域B内で積分すれば、領 域 $\mathrm{B}_{1}$ について有効情報量の期待值 $\mathrm{J}_{1}$ を求めることが できる。従って、Jは

$$
\begin{aligned}
J_{1} & =\int_{x=X-X^{\prime}}^{X_{0}-X^{\prime}} \int_{y=Y-Y^{\prime}}^{Y_{0}-Y^{\prime}} N\left(\frac{S}{S_{0}}\right)\left(1-\frac{S}{S_{0}}\right)^{N-1} \mathrm{dyd} x \\
& =N\left(\frac{S}{S_{0}}\right)\left(1-\frac{S}{S_{0}}\right)^{N-1}\left(X_{0}-X\right)\left(Y_{0}-Y\right)
\end{aligned}
$$

となる。 
(2)領域 $\mathrm{B}_{2} \sim \mathrm{B}_{5}$ に関する期待值 $\mathrm{J}_{2} \sim \mathrm{J}_{5}$

領域 $\mathrm{B}_{2}$ 内の点 $(x, y)$ に文字情報領域が一つだけ置か れる確率は、

$$
N\left(\frac{\left(x+X^{\prime}\right) Y}{S_{0}}\right)\left(1-\frac{\left(x+X^{\prime}\right) Y}{S_{0}}\right)^{N-1}
$$

である。従ってJ

$$
\begin{aligned}
J_{2} & =\int_{x=0}^{X-X^{\prime}} \int_{y=Y-Y_{0}}^{Y_{0}-Y^{\prime}} N\left(\frac{\left(x+X^{\prime}\right) Y}{S_{0}}\right)\left(1-\frac{\left(x+X^{\prime}\right) Y}{S_{0}}\right)^{N-1} \mathrm{dyd} x \\
& =\frac{\left(Y_{0}-Y\right)}{(N+1) Y}\left\{\left(N X^{\prime} Y+S_{0}\right)\left(1-\frac{X^{\prime} Y}{S_{0}}\right)^{N}-\left(N S+S_{0}\right)\left(1-\frac{S}{S_{0}}\right)^{N}\right\}
\end{aligned}
$$

と表される。以下同様に $\mathrm{J}_{3} \sim \mathrm{J}_{5} も$

$$
\begin{aligned}
& J_{3}=\frac{\left(Y_{0}-Y\right)}{(N+1) Y}\left[\left\{N\left(X-X^{\prime}\right) Y+S_{0}\right\}\left\{1-\frac{\left(X-X^{\prime}\right) Y}{S_{0}}\right\}^{N}-\left(N S+S_{0}\right)\left(1-\frac{S}{S_{0}}\right)^{N}\right] \\
& J_{4}=\frac{\left(X_{0}-X\right)}{(N+1) X}\left\{\left(N X Y^{\prime}+S_{0}\right)\left\{1-\frac{X Y^{\prime}}{S_{0}}\right)^{N}-\left(N S+S_{0}\right)\left(1-\frac{S}{S_{0}}\right)^{N}\right\} \\
& J_{S}=\frac{\left(X_{0}-X\right)}{(N+1) X}\left[\left\{N X\left(Y-Y^{\prime}\right)+S_{0}\right\}\left\{1-\frac{X\left(Y-Y^{\prime}\right)}{S_{0}}\right\}^{N}-\left(N S+S_{0}\right)\left(1-\frac{S}{S_{0}}\right)^{N}\right]
\end{aligned}
$$

となる。

(3)領域 $\mathrm{B}_{6} \sim \mathrm{B}_{9}$ に関する期待値 $\mathrm{J}_{6} \sim \mathrm{J}_{9}$

領域 $\mathrm{B}_{6}$ 内の点 $(\mathrm{x}, \mathrm{y})$ に文字情報領域が一つだけ置か れる確率は、

$$
\left.N\left\{\frac{\left(x+X^{\prime}\right)\left(y+Y^{\prime}\right)}{S_{0}}\right\} 1-\frac{\left(x+X^{\prime}\right)\left(y+Y^{\prime}\right)}{S_{0}}\right\}^{N-1}
$$

である。従ってJ。は

$$
\begin{aligned}
J_{6}= & \int_{x=0}^{X-X^{\prime}} \int_{y=0}^{Y-X} N\left\{\frac{\left(x+X^{\prime}\right)\left(y+Y^{\prime}\right)}{S_{0}}\right\}\left\{1-\frac{\left(x+X^{\prime}\right)\left(y+Y^{\prime}\right)}{S_{0}}\right\}^{N-1} \mathrm{~d} y \mathrm{~d} x \\
= & -\frac{1}{N+1}\left\{\sum_{i=1}^{N}\left(\begin{array}{c}
N \\
i
\end{array}\right)\left(-\frac{1}{S_{0}}\right)^{i} \frac{S_{0}}{i}\left(X^{i}-X^{\prime i}\right)\left(Y^{i}-Y^{i}\right)\right. \\
& \left.+\sum_{i=0}^{N}\left(\begin{array}{c}
N \\
i
\end{array}\right)\left(-\frac{1}{S_{0}}\right)^{i} \frac{N}{i+1}\left(X^{i+1}-X^{i+1}\right)\left(Y^{i+1}-Y^{i+1}\right)\right\} \quad(3.10)
\end{aligned}
$$

と計算される。 J 〜 J 代わりにそれぞれ(X-X', $\left.\mathrm{Y}^{\prime}\right) 、\left(\mathrm{X}^{\prime}, \mathrm{Y}-\mathrm{Y}^{\prime}\right) 、\left(\mathrm{X}-\mathrm{X}^{\prime}, \mathrm{Y}-\right.$
Y')を代入したものとなる。以上の結果を用い、全 領域における有效情報率の期待值は、

$$
\frac{\sum_{i=1}^{9} J_{i}}{N S}
$$

\section{と表される。}

ここで前節と同じように、点的施設と文字情報領 域の位置関係が有効情報率に与える影響を調べよう。 しかし、(3.11)式をこの形のままで扱うことは難し いので、文字情報領域の大きさが地図全体の大きさ と比べるとかなり小さいということを考虑し、 $S_{0} \gg S と い う$ 仮定を置いて近似的に式を展開しよう。 すると(3.11)式は次のように表される。

$$
\begin{aligned}
& \frac{1}{S_{0} S}\left[S\left\{1-(N-1) \frac{S}{S_{0}}\right\}\left(X_{0}-X\right)\left(Y_{0}-Y\right)\right. \\
& \quad+\frac{N\left(Y_{0}-Y\right) Y}{(N+1)}\left(X^{2}+2 X X^{\prime}-2 X^{\prime 2}\right) \\
& \quad+\frac{N\left(X_{0}-X\right) X}{(N+1)}\left(Y^{2}+2 Y Y^{\prime}-2 Y^{\prime 2}\right) \\
& \left.\quad+\frac{1}{4}\left(X^{2}+2 X X^{\prime}-2 X^{\prime 2}\right)\left(Y^{2}+2 Y Y^{\prime}-2 Y^{\prime 2}\right)\right]
\end{aligned}
$$

(3.12)式において、第1項はX、Y'にはよらず、第 2項は $\mathrm{X}^{\prime}=0$ あるいは $\mathrm{X}^{\prime}=\mathrm{X}$ で最小值、 $\mathrm{X}^{\prime}=\mathrm{X} / 2$ で最大 值、第 3 項は $Y^{\prime}=0$ あるいは $Y^{\prime}=Y$ のときに最小值、 $\mathrm{Y}^{\prime}=\mathrm{Y} / 2$ のきに最大值をとる。また第 4 項は、 $\mathrm{X}=0$ あるいはX'=X、さらにY'=0あるいはY'=Yのときに 最小值、 $X^{\prime}=X / 2$ かつ $Y^{\prime}=Y / 2 の と き に$ 最大値をとる。 従って、有効情報率の期待值もまた、文字情報領域 が図 5 (a)のように置かれた場合に最小になり、図 5 (c)のように置かれた場合に最大になることが分か る。

次に、(3.11)式を実際のディスプレイ画面に適用 してみよう。ここでも2節と同様に、ディスプレイ の大きさを横640、縦400ドットとし、その中に縦横 比 $1: 3$ の文字情報領域を持つN個の点的施設がう ンダムに配置されるものとする。また、文字情報領 
域は常に点的施設の右上に配置される、つまり、 $X_{i}^{\prime}=Y_{i}^{\prime}=0$ とする。

まず、点的施設の数 $\mathrm{N}=1 、 10 、 50 、 100 、 200 の$ 各場合について、文字情報領域の大きさと有効情報 率の期待値の関係を見てみよう（図 8）。

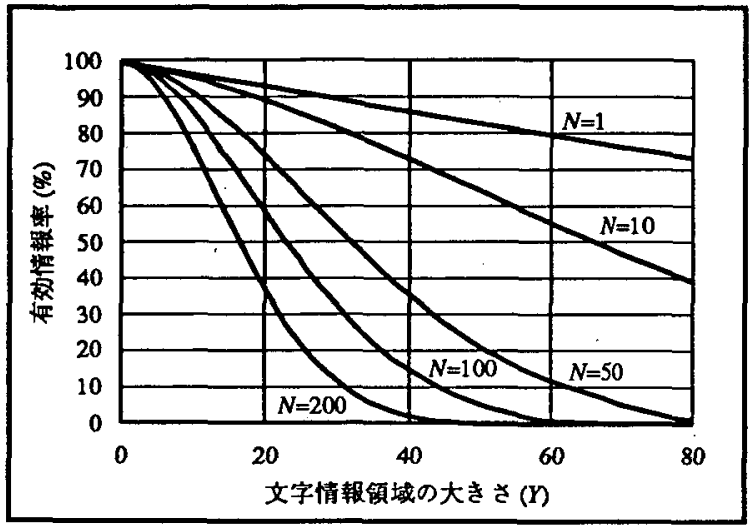

図 8 文字情報領域の大きさと有效情報率の期待値の 関係

図 8 を見ると、施設数が少ないときには有効情報 率と文字情報領域の関係は直線に近いが、施設数が 多い場合には、文字情報領域の大きさがある程度以 上になると有効情報率は急激に小さくなることがわ かる。 $\mathrm{N}=1$ のときにはほほ直線であるが、この場 合、有効情報率は画面内情報率と等しい。

次に、有効情報率の期待值が80、90、95\%の3つ の場合について、点的施設の数 $\mathrm{N}$ と文字情報領域の 大きさの関係を見よう（図9）。

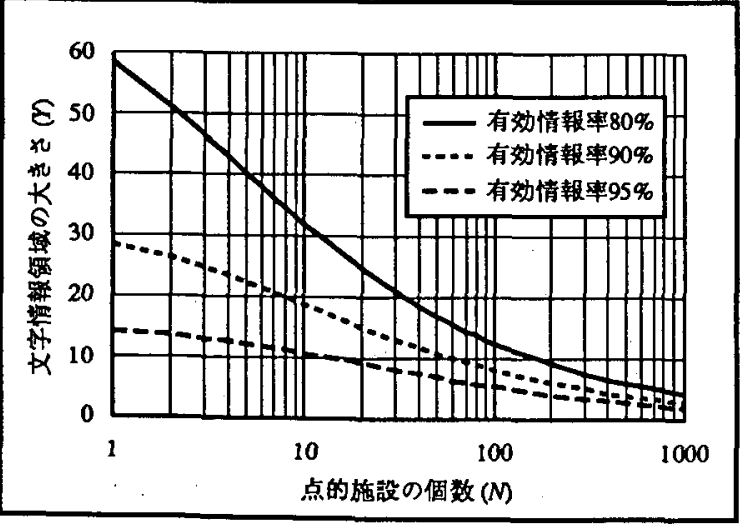

図 9 点的施設の数と文字情報領域の大きさの関係

いま、システムでは $12 \times 12$ ドット、 $16 \times 16$ ドッ ト、 $24 \times 24$ ドット 3 種類の字体が利用可能である
としょう。するとこの場合、有効情報率 $80 \%$ を確保 するには、施設数 $\mathrm{N}=21$ 以下であれば $24 \times 24$ ドット の字体を使うことができるが、N=22を超えると16 ドット、N=57を超えると 12 ドットの字体を使わな ければならない。さらに有効情報率 $90 \%$ を確保しよ うとする場合、 $\mathrm{N}=5$ 以上で 16 ドット、 $\mathrm{N}=17$ 以上で 12 ドットの字体を使わなければならないということが 図 9 から分かる。

地理情報システムに組み込まれているデータベー スソフトウェアの中には、各属性項目について項目 長の最大值を予め設定するものが少なくない。この ような場合について有効情報率の期待值を計算する ときには、実データの項目長を用いて(3.3)式を解く こともできるが、設定されている最大長を用いて式 (3.11)あるいは(3.12)を解くと、計算をより簡単に行 うことができる。もちろんこの場合、求められる有 効情報率の期待值は、より大きめの值となる。

\section{2 文字情報領域が施設の右上に配置される場合} 次に、点的施設と文字情報領域の位置関係の中で 最も一般的な場合として、文字情報領域が常に施設 の右上に配置される（ $X_{i}^{\prime}=Y_{i}^{\prime}=0 ）$ 場合を考えよう。 まず、ここではi<=jならば必ず $\mathrm{Y}_{\mathrm{i}}<=\mathrm{Y}_{\mathrm{j}}$ となるように $\left(X_{i} 、 Y_{i}\right)$ 並べ替える。さらに、ディスプレイ画面 を図10のような多くの領域に分割し、各領域内の点 に文字情報領域が一つだけ置かれる確率を求め、そ

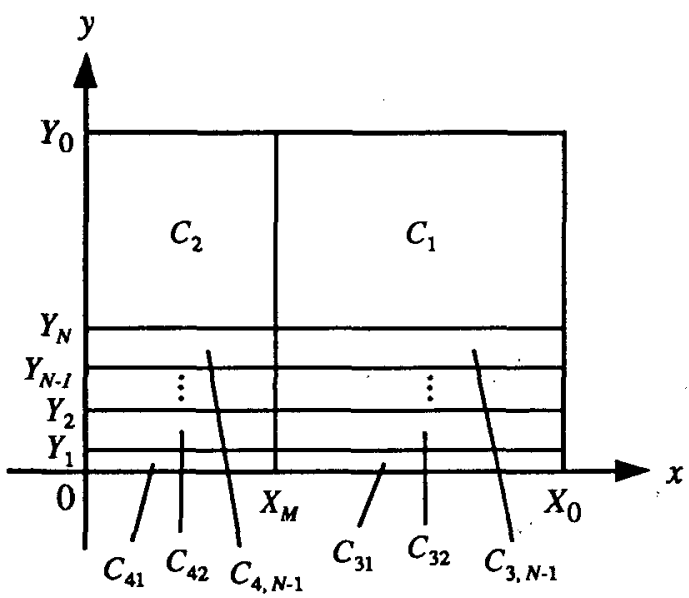

図10，有効情報率を計算するための領域分割 
の総和をとることによって有効情報量の期待値を計 算する。なお、ここでは領域iに関する有効情報量 の期待值の総和を $\mathrm{J}_{\mathrm{i}}$ とし、また $\mathrm{X}_{\mathrm{M}}=\max \left\{\mathrm{X}_{\mathrm{i}} ; \mathrm{i}=1, \ldots\right.$, N) と定義しておく。

(1)領域 $C_{1}$ に関する期待值 $\mathrm{J}_{1}$

領域C 1 内の点 $(x 、 y)$ に文字情報領域が一つだけ 置かれる確率は、

$$
\sum_{i=1}^{N}\left\{\left(\frac{S_{i}}{S_{0}}\right) \prod_{j=1}^{i-1}\left(1-\frac{S_{j}}{S_{0}}\right) \prod_{j=i+1}^{N}\left(1-\frac{S_{j}}{S_{0}}\right)\right\}
$$

である。この値を領域C で積分すると、有効情報量 の期待値

$$
J_{1}=\left(X_{0}-X_{M}\right)\left(Y_{0}-Y_{N}\right) \sum_{i=1}^{N}\left\{\left(\frac{S_{i}}{S_{0}}\right) \prod_{j=1}^{i-1}\left(1-\frac{S_{j}}{S_{0}}\right) \prod_{j=i+1}^{N}\left(1-\frac{S_{j}}{S_{0}}\right)\right\}
$$

と求めることができる。

(2)領域 $\mathrm{C}_{2}$ に関する期待值 $\mathrm{J}_{2}$

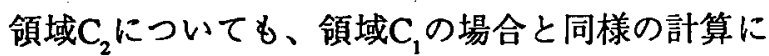
よって、有効情報量の期待値 $\mathrm{J}_{2}$ を求めることができ る。

$$
\begin{aligned}
J_{2}= & \left(Y_{0}-Y_{N}\right) \int_{x=0}^{X_{u}} \sum_{i=1}^{N}\left\{\left(\frac{Y_{i}}{S_{0}} \min \left\{X_{i}, x\right\}\right)\right. \\
& \left.\prod_{j=1}^{i-1}\left(1-\frac{Y_{j} \min \left\{X_{j}, x\right\}}{S_{0}}\right) \prod_{j=i+1}^{N}\left(1-\frac{Y_{j} \min \left\{X_{j}, x\right\}}{S_{0}}\right)\right\} \mathrm{d} x
\end{aligned}
$$

(3)領域 $\mathrm{C}_{3 \mathrm{i}}$ に関する期待値 $\mathrm{J}_{3 \mathrm{i}}$

領域内 $\mathrm{C}_{3 i}$ の点 $(\mathrm{x}, \mathrm{y})$ の上に、文字情報領域 $\mathrm{L}_{1} \sim \mathrm{L}_{\mathrm{i}-1}$ の中の一つが重ねて置かれる場合を考えると、その 確率 $\mathrm{p}_{\mathrm{i} 1}$ は

$$
p_{i 1}=\sum_{j=1}^{i-1}\left\{\left(\frac{S_{j}}{S_{0}}\right) \prod_{k=1}^{j-1}\left(1-\frac{S_{k}}{S_{0}}\right) \prod_{k=j+1}^{i-1}\left(1-\frac{S_{k}}{S_{0}}\right) \prod_{k=i}^{N}\left(1-\frac{X_{k} y}{S_{0}}\right)\right\}
$$

である。同様に、点 $(x, y)$ の上に文字情報領域 $L_{i} \sim L_{N}$ のどれか一つが置かれる確率 $p_{i 2}$ は

$$
p_{i 2}=\sum_{j=i}^{N}\left\{\left(\frac{X_{j} y}{S_{0}}\right) \prod_{k=1}^{i-1}\left(1-\frac{S_{k}}{S_{0}}\right) \prod_{k=i}^{j-1}\left(1-\frac{X_{k} y}{S_{0}}\right) \prod_{k=j+1}^{N}\left(1-\frac{X_{k} y}{S_{0}}\right)\right\}
$$

である。領域 $C_{3 i}$ に関する有効情報量 $J_{3 i}$ の期待值は、 $p_{i 1}$ 及び $p_{i}$ を領域内で積分することによって得られる。 従って、

$$
J_{3 i}=\left(X_{0}-X_{M}\right) \int_{y=Y_{1-1}}^{Y_{i}}\left(p_{i 1}+p_{i 2}\right) \mathrm{d} y
$$

となる。

(4)領域 $\mathrm{C}_{4 \mathrm{i}}$ に関する期待值 $\mathrm{J}_{4 \mathrm{i}}$

領域内 $\mathrm{C}_{4 \mathrm{i}}$ の点 $(\mathrm{x}, \mathrm{y})$ に、文字情報領域 $\mathrm{L}_{1} \sim \mathrm{L}_{\mathrm{i}-1}$ の中 の一つが重ねられる確率 $p_{\mathrm{i} 1}$ は

$$
\begin{aligned}
p_{i 1}= & \sum_{j=1}^{i-1}\left\{\left(\frac{Y_{j}}{S_{0}} \min \left\{X_{j}, x\right\}\right) \prod_{k=1}^{j-1}\left(1-\frac{Y_{k} \min \left\{X_{k}, x\right\}}{S_{0}}\right)\right. \\
& \left.\prod_{k=j+1}^{i-1}\left(1-\frac{Y_{k} \min \left\{X_{k}, x\right\}}{S_{0}}\right) \prod_{k=i}^{N}\left(1-\frac{y \min \left\{X_{k}, x\right\}}{S_{0}}\right)\right\}
\end{aligned}
$$

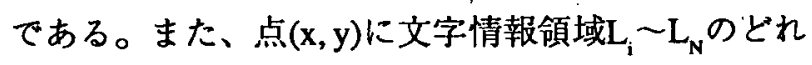
か一つが置かれる確率 $\mathrm{p}_{\mathrm{i} 2}$ は

$$
\begin{aligned}
p_{i 2}= & \sum_{j=i}^{N}\left\{\left(\frac{y}{S_{0}} \min \left\{X_{j}, x\right\}\right) \prod_{k=1}^{i-1}\left(1-\frac{Y_{k} \min \left\{X_{k}, x\right\}}{S_{0}}\right)\right. \\
& \left.\prod_{k=i}^{j-1}\left(1-\frac{y \min \left\{X_{k}, x\right\}}{S_{0}}\right) \prod_{k=j+1}^{N}\left(1-\frac{y \min \left\{X_{k}, x\right\}}{S_{0}}\right)\right\}
\end{aligned}
$$

である。従って、領域 $\mathrm{C}_{4 \mathrm{i}}$ に関する有效情報量 $\mathrm{J}_{4 \mathrm{i}}$ の期 待値は

$$
J_{4 i}=\int_{x=0}^{X_{\nu}} \int_{y=Y_{i-1}}^{Y_{i}}\left(p_{i 1}+p_{i 2}\right) \mathrm{d} y \mathrm{~d} x
$$

となる。

以上の結果を用いると、有効情報率の期待値は次 のように表されることになる。

$$
\mathrm{E}\left[I_{\text {eff }}\right]=\frac{J_{1}+J_{2}+\sum_{i=1}^{N-1}\left(J_{3 i}+J_{4 i}\right)}{\sum_{i=1}^{N} S_{i}}
$$




\section{4. 横浜市の鉄道駅名称の配置}

以上のように、本論文では画面内情報率と有効情 報率という二つの指標を用いて、文字の大きさが文 字情報の損失に与える影響を定量化する方法を提案 した。本節では前2節の結果を用い、横浜市におけ る鉄道駅の名称を地図に配置した例を示す。

ここでは文字の大きさを決定する基準として、有 効情報率の期待值が $80 \%$ 、90\%、95\%となる場合を 考える。具体的には、鉄道駅の名称は全て駅の右上 に表示されるものとし、3.2節における分析結果を 適用する。横浜市における鉄道駅の総数は117であ り、横浜市全域を完全に内包する絴 $235 \mathrm{~mm}$ 、横 $172 \mathrm{~mm}$ の長方形画面（縦置きのA4サイズに収まる 大きさ）ににこれらの駅を表示すると仮定すると、 文字情報領域の大きさ（維の長さ）はそれぞれ、 $\mathrm{Y}=4.607 \mathrm{~mm} 、 3.024 \mathrm{~mm} 、 1.904 \mathrm{~mm}$ となる。これら 3 つの場合について、画面内情報率の期待値、実際に その大きさで文字を配置したときの有効情報率と画 面内情報率を計算した結果が表1である。また、 $\mathrm{Y}=3.024 \mathrm{~mm}$ の場合における実際の名称配置例を図 11 に示す。

表 1 画面配置時における鉄道駅名称の情報率

\begin{tabular}{|l|rrr|}
\hline 文字の大きさ $(Y, \mathrm{~mm})$ & 4.607 & 3.024 & 1.904 \\
\hline 画面内情報率の期待値 $(\%)$ & 94.66 & 96.65 & 97.78 \\
実際の画面内情報率 $(\%)$ & 99.45 & 100.00 & 100.00 \\
\hline 有効情報率の期待値 $(\%)$ & 80 & 90 & 95 \\
実際の有効情報率 $(\%)$ & 68.28 & 88.03 & 94.20 \\
\hline
\end{tabular}

まず、表1を見てみよう。この例では、実際の有 効情報率は3つの場合全てについて期待值を下回っ ている。これは図11から分かるとおり、駅の分布が 市域の東部に集中しており、必ずしもランダムな分 布とは言えないことが原因であろうと思われる。ま た、画面内情報率を期待值と実際の值とで比べてみ ると、実際の値は全て期待值を上回っている。これ は、市域が完全に内包されるような表示方法を用い たために、画面境界付近に位置する駅がほとんどな いことによる。従って、例えば市域の一部を拡大表
示すると、画面内情報率はこれほど高くはならない と考えられる。

次に図11を見てみよう。図11の有効情報率は $88 \%$ であり、数字だけを見ると決して低い值ではない。 にもかかからず、文字同士の重複はかなり多く感じ られる。この理由の一つとしては、重複の見られる 文字情報が一部の地域に集中していることが考えら れる。この例のように、文字によって重複の度合い にばらつきがあると、全ての文字が平均的に重複し ている場合と比べて、推測によって判読できる文字 の量が減少するため、見た目以上に文字同士が重複 しているような印象を与えるものと思われる。この 現象も、やはり先程と同じょうに、施設の分布がラ ンダムではないことに起因している。従って、点的 施設の分布が集中型に近いと分かっている場合や、 分布について何も情報がない場合には、文字の大き さはより小さめに設定すべきであろうと考えられ る。

\section{5.おわりに}

本論文では、画面内情報率と有效情報率という二 つの指標を用い、地理情報システムにおいて、文字 の大きさが文字情報の重複やはみ出しなどの損失に 与える影響を定量化し、文字情報の損失を一定の水 準以下に抑えるための文字の大きさを統計的に計算 する方法を示した。さらに、この結果を横浜市にお ける鉄道駅名称の配置に適用し、実証分析を行っ た。

ここで得られた分析結果を適用することで、地理 情報システムが文字情報を完全に機械的に配置する 場合には、文字情報の損失をある水準に抑制するこ とが可能となる。また、自動文字配置アルゴリズム においても、機械的配置における文字の大きさの基 準を安全側の基準值として用いることができる。

本論文で提案した情報率の計算方法は、計算が容 易であるということに一つの特徴がある。(2.11)式 は極めて単純な四則演算であり、(3.11)式も画面の 大きさに対して文字情報が小さいという仮定のもと 


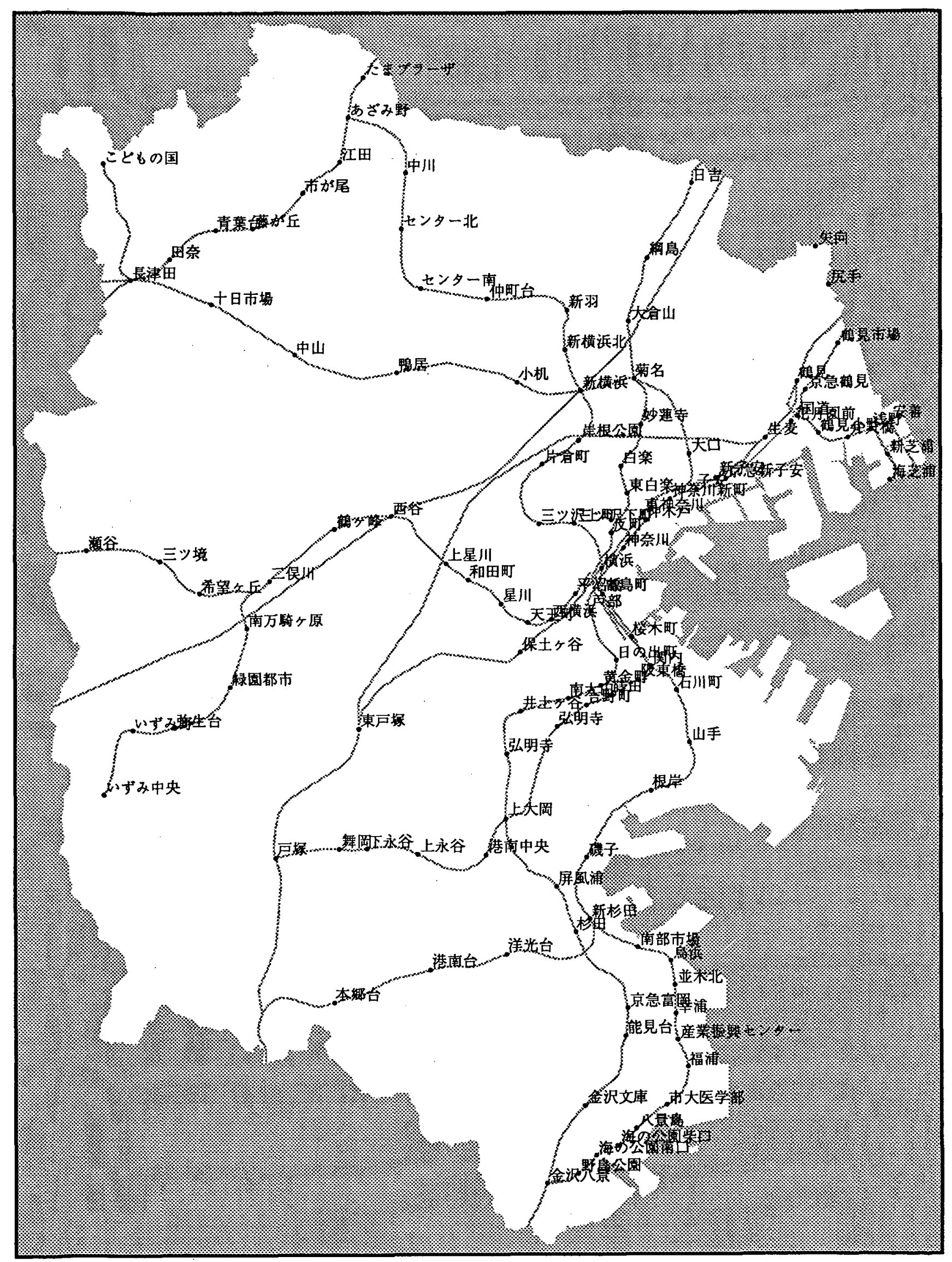

図11 横捠市における鉄道駅の名称配置例（Y=3.024mm） 
では(3.12)式のように簡単に表わされる。従って、 迅速な表示が求められる状況においては、これらの 式を用いて情報の損失を簡単に制御することが可能 となる。

文字の大きさを決定する基準として、画面内情報 率と有効情報率のどちらを用いるべきか、また、文 字のはみ出しや重複をどの程度に抑えるべきなのか という問題については、本論文は直接研究対象とは していない。これは、利用者の要求やシステムの能 力などによって、情報率の基準や文字の判読可能性 が大きく変化すると考えられるためである。例えば、 画面から文字がはみ出すことが致命的な問題となる 場合には、画面内情報率を基準とすべきであり、文 字情報の数が多く、重複によって判読が困難になる 場合には、有效情報率を用いる心゙きであろう。また 利用者が大きめの字を好む場合には、情報率の基準 は若干低めに設定する必要があるだろう。従って地 理情報システムは、利用者が希望する情報率を指示 すれば、それに応じた文字の大きさを自動的に設定 する機能を提供することが望ましい。

文字の大きさの統計的決定方法については、本論 文で取り上げた文字同士の重複やはみ出し以外にも、 '文字と空間対象物の重複を考慮した場合、線的・面 的施設における文字配置、文字配置アルゴリズムを 用いた場合の分析など、さらに多くの場合について 研究を行う必要がある。これらの問題については、 今後の課題としたい。

\section{参考文献}

Ahn, J. and H. Freeman (1983): "A Program for Automated Name Placement," Proceedings, Auto-Carto 6, 444-453.

Basoglu, U. (1982): "A New Approach to Automated Name Placement," Proceedings, Auto-Carto 5, 103122.

Brassel, K. E. and R. Weibel (1988): "A Review and Conceptual Framework of Automated Map Generalization," International Journal of Geographical Information Systems, 2, 3, 229-244.
Buttenfield, B. P. and R. B. McMaster (1991): Map Generalization: Making Rules for Knowledge Representation. Longman, London.

Doerschler, J. S. and H. Freeman (1989): "An Expert System for Dense-map Name Placement," Proceedings, Auto-Carto 9, 215-224.

Ebinger, L. R. and A. M. Goulette (1989): "Automated Names Placement in a Non-Interactive Environment," Proceedings, Auto-Carto 9, 205-214.

Formann, M. and F. Wagner (1991): "A Packing Problem with Applications to Lettering of Maps," Proceedings of the Seventh Annual Symposium on Cumputational Geometry, 281-288.

Hirsch, S. A. (1982): "An Algorithm for Automatic Name Placement around Point Data," The American Cartographer, 9, 1, 5-17.

Imhof, E. (1975): "Positioning Names on Maps," The American Cartographer, 2, 2, 128-144.

Langran, M. S. and T. K. Poiker (1986): "Integration of Name Selection and Name Placement," Proceedings, Second International Symposium on Spatial Data Handling, 50-64.

Monmonier, M. S. (1982): Computer-Assisted Cartography Principles and Prospects. Prentice-Hall, Englewood Cliffs, New Jersey.

Mower, J. E. (1986): "Name Placement of Point Features Through Constraint Propagation," Proceedings, Second International Symposium on Spatial Data Handling, 65-73.

Robinson, A., R. Sale, and J. Morrison (1978): Elements of Cartography. John Wiley \& Sons, New York.

Yoeli, P. (1972): "The Logic of Automated Map Lettering," The Cartographic Journal, 9, 2, 99-108.

Zoraster, S. (1986): "Integer Programming Applied to the Map Label Placement Problem," Cartographica, 23, 3, 16-27.

Zoraster, S. and B. Stephen (1987): "Practical Experience with a Map Label Placement Program," Proceedings, Auto-Carto 8, 701-708. 